\title{
Effect of Cathepsin D Treatment on ATPase Activity of Rabbit Myofibril ${ }^{\dagger}$
}

\author{
By Akihiro Okitani, Atsushi Suzuki,* Ryung Yang \\ and Masao FuJimaki \\ Department of Agricultural Chemistry, Faculty of \\ Agriculture, The University of Tokyo, \\ Received May 4, 1972
}

\begin{abstract}
The effect of cathepsin $\mathrm{D}$ and pepsin treatment on rabbit myofibril was studied by measuring the amount of proteolytic products and Mg-enhanced ATPase activity.

When myofibril was treated with cathepsin $\mathrm{D}$ at $3^{\circ} \mathrm{C}$ and $\mathrm{pH} 5.0$ or 5.5 , a little but detectable amount of nonprotein nitrogenous compounds was released. However, there was no change in ATPase activity of myofibril, though treated with cathepsin D of higher units than assumed to be in muscle.

When myofibril was treated with pepsin under the same condition as used above, there was an increase in $\mathrm{KCl}$-concentration dependence of ATPase activity followed by a decrease in the maximal value of ATPase activity.

From the present results, it was concluded that cathepsin D might not take a main role on the post-mortem degradation of myofibril.
\end{abstract}

It has been suggested by many workers ${ }^{1,}$ that the degradation or fragmentation of myofibril may proceed during post-mortem storage of muscle and that its process may be initiated at Z-line and/or I-Z junction. It has also been revealed that there is an increase in $\mathrm{KCl}$-concentration dependence of $\mathrm{Mg}$ enhanced ATPase activity of myofibril during post-mortem storage, which may accompany the degradation of myofibril. ${ }^{2}$ Thus, the degradation of myofibril has been assumed to relate with the post-mortem tenderization of muscle, while the mechanism of the degradation has not been cleared.

Cathepsin D was isolated and highly purified from rabbit muscle previously by the authors. ${ }^{3 \prime}$ It was also shown that cathepsin D could hydrolyze not only sarcoplasmic protein but also myofibrilar proteins. ${ }^{4)}$ Therefore, the

\footnotetext{
t Studies on Proteolysis in Stored Muscle. Part V.

* Present address: Department of Animal Husbandary, Niigata University, Niigata.
}

present work was conducted to examine whether or not cathepsin D catalyze the postmortem degradation of myofibril. At the same time, myofibril was treated with pepsin the proteolytic specificity of which was similar to cathepsin $D,{ }^{51}$ and the effect was compared with that of cathepsin D.

\section{MATERIALS AND METHODS}

Cathepsin D. Purified cathepsin D was prepared from rabbit muscle $(l$. dorsi) immediately after slaughter according to the method described in the previous paper. ${ }^{31}$

Myofibril. The longissimus dorsi muscle was removed from a newly-killed rabbit and minced. After storage at $4^{\circ} \mathrm{C}$ for 1 day, the minced meat $(5 \mathrm{~g})$ was homogenized in Waring blender with $40 \mathrm{ml}$ of $0.16 \mathrm{M}$ $\mathrm{KCl}-0.04 \mathrm{M}$ tris- $\mathrm{HCl}$ buffer solution $(\mathrm{pH} 7.5)$ for $1 \mathrm{~min}$. The successive procedure was done in the same way as in the previous paper. ${ }^{21}$

Nonprotein muscle extract. The minced muscle 
$(15 \mathrm{~g})$ was homogenized with $30 \mathrm{ml}$ of deionized water for $3 \mathrm{~min}$. The homogenate was centrifuged at $78,000 \times g$ for $2 \mathrm{hr}$ and the supernatant obtained was filtrated through a collodion bag in vacuo to remove macromolecular substances. The filtrate was used as nonprotein muscle extract.

Urea-denatured hemoglobin. Hemoglobin solution dialyzed against deionized water was denatured with 3 M urea.

Muscle homogenate. Minced muscle $(7 \mathrm{~g})$ was homogenized with $31 \mathrm{ml}$ of $0.2 \mathrm{M} \mathrm{Na}$ - acetate- $\mathrm{HCl}$ buffer solution ( $\mathrm{pH} 2.4$ ) and $4 \mathrm{ml}$ of $1000 \mathrm{ppm}$ chloramphenicol for $1 \mathrm{~min}$. The $\mathrm{pH}$ value of the obtained homogenate was 4.0 , which was optimal for assay of cathepsin $\mathrm{D}$ activity.

Concentration of Cathepsin $D$ and pepsin. The concentration of cathepsin $\mathbf{D}$ and hog pepsin (Washington Biochem. Co., twice crystallized) was expressed as proteolytic activity unit. The amount of the enzyme which released one micromole tyrosine equivalent per minute from urea-denatured hemoglobin when assayed at $\mathrm{pH} 4.0$ and $37^{\circ} \mathrm{C}$ for $1 \mathrm{hr}$ was regarded as one unit of cathepsin $\mathrm{D}$ and pepsin.

Measurement of proteolytic products. After the incubation was stopped with trichloroacetic acid (TCA), the amount of the proteolytic products in TCA-soluble fraction was determined by the method of Lowry et $a l^{6}$ and expressed as tyrosine equivalents. When nonprotein muscle extract was contained in the incubation media, the value was corrected for its inhibitory effect on the color developement of phenol reagent (see Results).

Cathepsin D or pepsin treatment on myofibril. Myofibril was incubated with cathepsin $\mathrm{D}$ or pepsin in $0.15 \mathrm{M} \mathrm{KCl}-5 \mathrm{~mm} \mathrm{Na}$-acetate- $\mathrm{HCl}$ buffer solution at $3^{\circ} \mathrm{C}$ and $\mathrm{pH} 5.0$ or 5.5. The proteolytic action was stopped with $0.04 \mathrm{M}$ tris-maleate $(\mathrm{pH} 7.0$ ) or TCA and the mixture was used for determination of ATP. ase activity or proteolytic products.

Mgenhanced ATPase activity measurements. After myofibril $(0.1 \mathrm{mg} / \mathrm{ml})$ was incubated with $1 \mathrm{mM}$ ATP and $1 \mathrm{mM} \mathrm{MgCl}_{2}$ at $25^{\circ} \mathrm{C}$ for $10 \mathrm{~min}$, the reaction was stopped with TCA and the liberated phosphorus was determined by the modified Allen's method." Composition of the incubation mixture was shown in each figure.

Protein concentration. Protein concentration was estimated by biuret method ${ }^{8}$ which was standardized by micro-kjeldahl method.

\section{RESULTS}

Effect of nonprotein muscle extract on the proteolytic activity of cathepsin $D$

It was examined whether or not muscle contained any substance to regulate the proteolytic activity of cathepsin D. When cathepsin $D$ was acted on hemoglobin in the presence and the absence of nonprotein muscle extract, the result was obtained as shown in Table I. The nonprotein nitrogenous com-

\section{Table I. Effect of Nonprotein Muscle Extract} on Proteolytic Activity of Cathepsin D

Urea-denatured hemoglobin was incubated with cathepsin $D$ in the presence or absence of nonprotein muscle extract solution diluted with 3 volumes of water in $50 \mathrm{~mm}$ Na-acetate- $\mathrm{HCl}$ buffer solution at $\mathrm{pH} 4.0$ and $37^{\circ} \mathrm{C}$. After $1 \mathrm{hr}$-incubation, an equal volume of $6 \%$ TCA was added, and the filtrate was determined by phenol reagent. Corrected values were obtained by application of the inhibition rate of the color development obtained from Fig. 1.

\begin{tabular}{lcc}
\multirow{2}{*}{ Additives } & \multicolumn{2}{c}{ Increment of $E_{500 \mathrm{~m} \mu} / \mathrm{hr}$} \\
\cline { 2 - 3 } & Appeared & Corrected \\
\hline Nonprotein extracts & 0.011 & 0.016 \\
$\begin{array}{l}\text { Hemoglobin } \\
\text { Nonprotein extracts, } \\
\text { hemoglobin }\end{array}$ & 0.083 & 0.083 \\
\hline
\end{tabular}

pounds were less released from hemoglobin in the presence of the nonprotein muscle extract than in its absence. Thus muscle seemed to contain substances to inhibit the proteolytic activity of cathepsin D. However, it was revealed that the color development of phenol reagent was considerably inhibited when a protein was estimated by Lowry's method $^{6}$ ) in the presence of nonprotein muscle extract, as shown in Fig. 1. Therefore, applying the color inhibition rate obtained from Fig. 1, the value in Table I was corrected to 


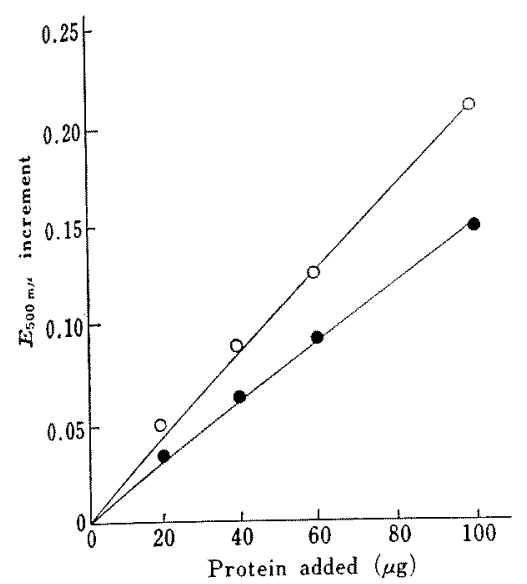

FIG. 1. Inhibitory Effect of Nonprotein Muscle Extract on Color Development of Phenol Reagent.

Protein was determined in the presence (e) or absence $(0)$ of nonprotein muscle extract solution diluted with 7 volumes of water.

that at zero of the inhibition rate of the color developement. The corrected value indicated that there was neither an activator nor an inhibitor of cathepsin $\mathrm{D}$ in the nonprotein muscle extract.

Proteolytic activity of cathepsin $D$ on myofibril When myofibril was incubated with 7 milli- unit $(\mathrm{mU}) / \mathrm{ml}$ of cathepsin $\mathrm{D}$ at $3^{\circ} \mathrm{C}$ and $\mathrm{pH}$ $4.0,5.0$ or 5.5 for 10 days, the nonprotein nitrogenous compounds released were determined with phenol reagent. As shown in Table II, the result indicated that the proteolytic activity at $\mathrm{pH} 4.0$ was most remarkable and that at $\mathrm{pH} 5.0$ and 5.5 was $17.4 \%$ and $3.7 \%$ of that at $\mathrm{pH} 4.0$, respectively. The proteolysis was depressed in the presence of $\mathrm{CaCl}_{2}$. The addition of Triton X-100 enhanced the proteolysis at $\mathrm{pH}$ 5.5. Even though cathepsin $\mathrm{D}$ was not added, proteolysis occurred at $\mathrm{pH} 4.0$, and moreover, at $\mathrm{pH} 5.0$ and 5.5 in the presence of Triton $X-100$. This result suggests that the myofibril preparation contains cathepsins (including cathepsin D) which are in a latent form by intervention of lipids and so on.

The $\mathrm{pH}$ dependence of the proteolytic activity on hemoglobin of pepsin and rabbit muscle cathepsin D are well known. However, both were reexamined under the same condition for facilities of comparison with the activity on myofibril. As shown in Table III, the activity of cathepsin D at $\mathrm{pH} 5.0$ and 5.5 was $21.5 \%$ and $4.7 \%$ of that at $\mathrm{pH} 4.0$, respectively. Accordingly, the $\mathrm{pH}$ dependence

\section{Table II. NONProtein Nitrogenous Compoundos Released from MYOFIBRIL BY CATHEPSIN D TREATMENT}

Figures show the total amounts released from $6 \mathrm{mg}$ myofibril after incubation with or without $28 \mathrm{mU}$ cathepsin $\mathrm{D}$ at $3^{5} \mathrm{C}$ for 10 days in $4 \mathrm{ml}$ of $0.15 \mathrm{M} \mathrm{KCl}-5 \mathrm{~mm} \mathrm{Na}$-acetate- $\mathrm{HCl}$ buffer solution, when added, containing $1 \mathrm{mM} \mathrm{CaCl}$ and $0.2 \%$ Triton $\mathrm{X}-100$.

Values in parentheses are expressed as \% of the value at $\mathrm{pH} 4.0$.

\begin{tabular}{|c|c|c|c|}
\hline \multirow{3}{*}{ Additives } & \multicolumn{3}{|c|}{$\begin{array}{l}\text { Phenol reagent positive materials } \\
\text { as "g tyrosine equivalents }\end{array}$} \\
\hline & \multicolumn{3}{|c|}{ Incubation $\mathrm{pH}$} \\
\hline & 5.5 & 5.0 & 4.0 \\
\hline - & 0 & 0 & 6.6 \\
\hline, $\mathrm{CaCl}_{2}$ & 0 & 0 & 4.8 \\
\hline$-\quad$ Triton $\mathrm{X}-100$ & 4.2 & 7.8 & 21.6 \\
\hline Cathepsin D, - & $4.8(3.7)$ & $24.6(17.4)$ & $130.2(100)$ \\
\hline Cathepsin $\mathrm{D}, \mathrm{CaCl}_{2}$ & 3.0 & 15.6 & 115.8 \\
\hline Cathepsin D, Triton X-100 & 12.0 & - & - \\
\hline
\end{tabular}


Table III. pH-Dependence of Proteolytic Activity of Cathepsin D and Pepsin

Urea-denatured hemoglobin was incubated with cathepsin $\mathrm{D}$ or pepsin in $50 \mathrm{~mm} \mathrm{Na-acetate- \textrm {HCl }}$ buffer solution at $37^{\circ} \mathrm{C}$ for $1 \mathrm{hr}$. Activity is shown as $\%$ of the value at $\mathrm{pH} 4.0$.

\begin{tabular}{ccc}
\hline \multirow{2}{*}{$\mathrm{pH}$} & \multicolumn{2}{c}{ Relative activity $(\%)$} \\
\cline { 2 - 3 } & Cathepsin D & Pepsin \\
\hline 4.0 & 100 & 100 \\
5.0 & 21.5 & 14.1 \\
5.5 & 4.7 & 6.9 \\
\hline
\end{tabular}

of the proteolytic activity of cathepsin D on myofibril was similar to that on hemoglobin. In the present paper, pepsin was used in comparison with cathepsin $\mathrm{D}$ at $\mathrm{pH} 5.0$ and 5.5. The $\mathrm{pH}$ dependence of the proteolytic activity of pepsin was similar to that of cathep$\sin \mathrm{D}$ when hemoglobin was used as substrate at $\mathrm{pH} 4.0 \sim 5.5$ (Table III).

\section{Effect of cathepsin D treatment on ATPase activity of myofibril}

The result shown in Table II indicated that cathepsin D hydrolyzed myofibril at $\mathrm{pH} 5.0$ to 5.5 where muscle reached post-mortem. It was, therefore, studied how myofibril changed during proteolysis. Among many characteristics, Mg-enhanced ATPase activity was chosen to follow the change of myofibril. It has been previously reported by the authors that there is a change in Mg-enhanced ATPase activity of myofibril during postmortem storage of muscle, which may accompany the degradation of myofibril. ${ }^{2}$ It has also been shown that there is a marked change in $\mathrm{Mg}$ enhanced ATPase activity, when myofibril is treated with a proteinase, trypsin ${ }^{9}$ or pepsin (see below). Therefore, it was assumed that Mg-enhanced ATPase activity was available to detect the changes involving the degradation of myofibril treated with a proteinase, cathepsin D.

When myofibril is incubated with cathepsin
D to reveal its post-morten effect on myofibril the activity of the enzyme must be comparabl with that at in situ muscle. Although it wa difficult to know the accurate activity 0 cathepsin D in muscle, it was roughly estimat ed by the experiment where the nonproteil nitrogenous compounds released were deter mined when muscle homogenate was incubate with hemoglobin. When muscle homogenat was incubated with hemoglobin at $37^{\circ} \mathrm{C}$ an $\mathrm{pH} 4.0$, about $200 \mu \mathrm{g}$ tryosine equivalent released for $1 \mathrm{hr}$ per $1 \mathrm{~g}$ muscle. Supposer that all the proteolytic activities of muscl homogenate at $\mathrm{pH} 4.0$ are ascribed to cathepsis $\mathrm{D}$, cathepsin D may be contained in muscl at about $20 \mathrm{mU} / \mathrm{ml}$.

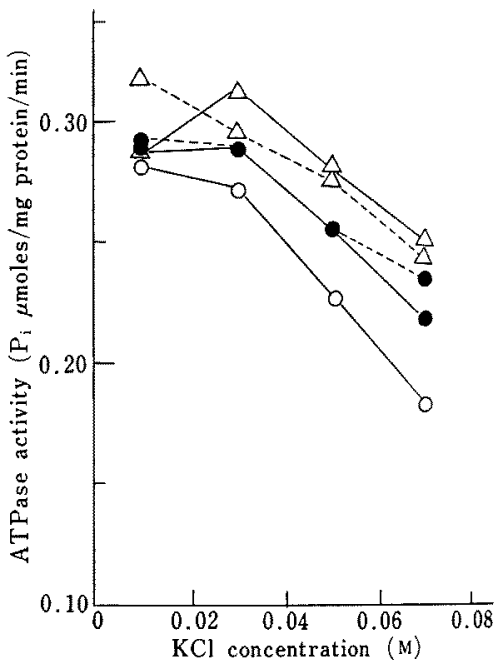

FIG. 2. ATPase Activity of Myofibril after Treat ment with Cathepsin $\mathrm{D}$ at $\mathrm{pH} 5.5$.

Cathepsin D treatment: $1.5 \mathrm{mg} / \mathrm{ml}$ myofibri was incubated with or without cathepsin $\mathrm{D}(80 \mathrm{mU}$ $\mathrm{ml}$ ) in $0.15 \mathrm{M} \mathrm{KCl}-5 \mathrm{~mm} \mathrm{Na}$-acetate- $\mathrm{HCl}$ buffer solution at $\mathrm{pH} 5.5$ and $3^{\circ} \mathrm{C}$ for 10 and 15 days.

ATPase was assayed in the following mixture al $25^{\circ} \mathrm{C}$ and $\mathrm{pH} 7.5$ for $10 \mathrm{~min} ; 0.1 \mathrm{mg} / \mathrm{ml}$ myofibril $1 \mathrm{mM}$ ATP, $1 \mathrm{mM} \mathrm{MgCl}, 7 \mathrm{~mm}$ tris and $\mathrm{KCl}$ al concentrations cited on the abscissa.

O-O: 0 day, - 10 days, without cathepsin D

- 10 days, with cathepsin $\mathrm{D}, \Delta-\Delta: 15$ days without cathepsin $D, \triangle--\triangle: 15$ days, with cathepsir D. 


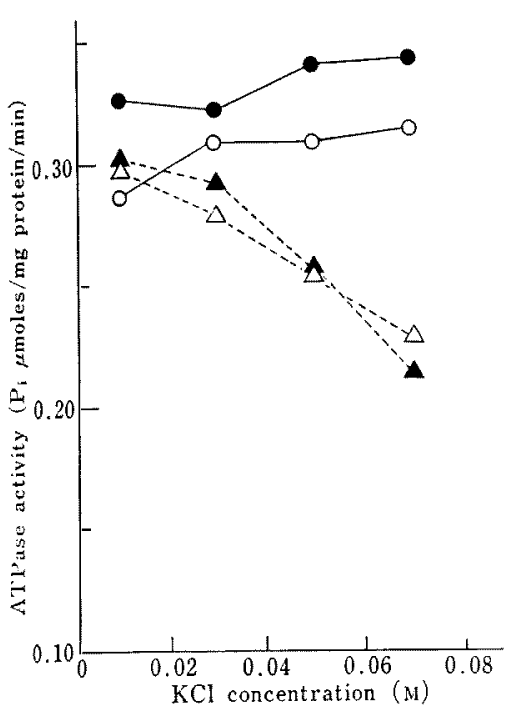

Fic. 3. ATPase Activity of Myofibril after Treatment with Pepsin at $\mathrm{pH}$ 5.5.

Pepsin treatment: $1.5 \mathrm{mg} / \mathrm{ml}$ myofibril was incubated with or without pepsin $(14 \mathrm{mU} / \mathrm{ml}$ or $28 \mathrm{mU} / \mathrm{ml}$ ) in $0.15 \mathrm{M} \mathrm{KCl}-5 \mathrm{~mm} \mathrm{Na}$-acetate- $\mathrm{HCl}$ buffer solution at $\mathrm{pH} 5.5$ and $3^{\circ} \mathrm{C}$ for 3 days.

ATPase was assayed as in Fig. 1.

0-0: 0 day, - 3 days, without pepsin, $\triangle \cdots: 3$ days, with $14 \mathrm{mU} / \mathrm{ml}$ pepsin, $\Delta \cdots--\Delta: 3$ days, with $28 \mathrm{mU} / \mathrm{ml}$ pepsin

When myofibril was incubated at $3^{\circ} \mathrm{C}$ and $\mathrm{pH} 5.5$ for 15 days with cathepsin $\mathrm{D}$ of $80 \mathrm{mU} / \mathrm{ml}$ which was 4 times the amount assumed in muscle, there was no difference in ATPase activity from the myofibril incubated without cathepsin D, as shown in Fig. 2.

In comparison, myofibril was incubated under the same condition with pepsin of 14 and $28 \mathrm{mU} / \mathrm{ml}$, whose activity on hemoglobin at pH 5.5 was identical to 20 and $40 \mathrm{mU} / \mathrm{ml}$ of cathepsin D respectively, according to the result in Table III. As shown in Fig. 3, $\mathrm{KCl}$-concentration dependence of ATPase activity increased remarkably after 3 dayincubation as compared with the control.

Myofibril was incubated with or without $28 \mathrm{mU} / \mathrm{ml}$ cathepsin $\mathrm{D}$ for 10 days at $3^{\circ} \mathrm{C}$ and

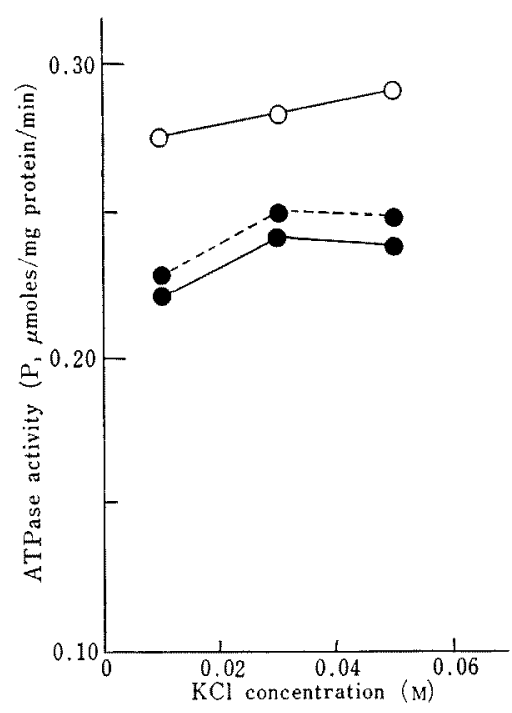

FIG. 4. ATPase Activity of Myofibril after Treatments with Cathepsin D at pH 5.0.

Cathepsin D treatment: $1.5 \mathrm{mg} / \mathrm{ml}$ myofibril was incubated with or without cathepsin $\mathrm{D}(28 \mathrm{mU} /$ $\mathrm{ml}$ ) in $0.15 \mathrm{M} \mathrm{KCl}-5 \mathrm{~mm} \mathrm{Na}$-acetate- $\mathrm{HCl}$ buffer solution at $\mathrm{pH} 5.0$ and $3^{\circ} \mathrm{C}$ for 10 days.

ATPase was assayed as in Fig. 1.

Symbols are the same as in Fig. 2.

$\mathrm{pH} 5.0$, which was nearer to the optimal $\mathrm{pH}$ of cathepsin D than $\mathrm{pH}$ 5.5. As shown in Fig. 4, ATPase activity decreased after 10 day-incubation, however, there was no difference between the myofibrils incubated with and without cathepsin D.

When myofibril was incubated at $3^{\circ} \mathrm{C}$ and $\mathrm{pH} 5.0$ with 14 or $28 \mathrm{mU} / \mathrm{ml}$ pepsin for 3 days, $\mathrm{KCl}$-concentration dependence of ATPase activity increased more remarkably than at $\mathrm{pH}$ 5.5, as shown in Fig. 5.

When myofibril was incubated with cathep$\sin \mathrm{D}$ at $3^{\circ} \mathrm{C}$ and $\mathrm{pH} 4.0$, which was optimal $\mathrm{pH}$ of this enzyme, ATPase activity decreased so rapidly that the effect of cathepsin D could not be detected.

As the above-mentioned results suggested that cathepsin D more hardly attacked a native protein than pepsin did, a partiallydenatured myofibril was incubated with cathep- 


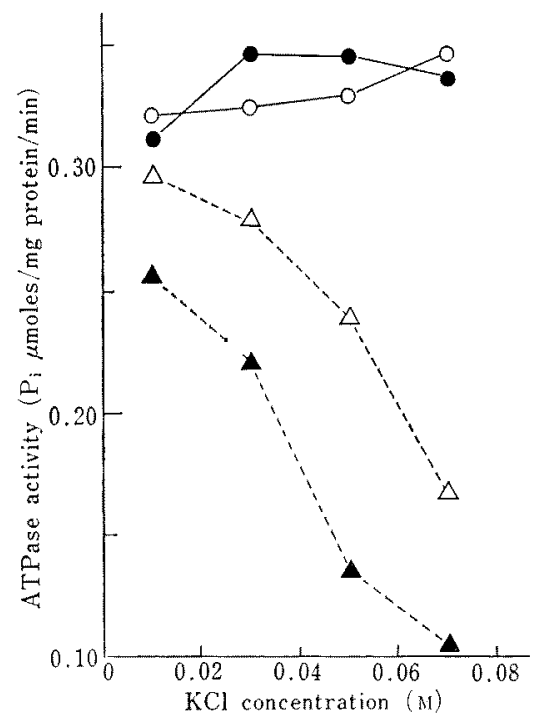

FIG. 5. ATPase Activity of Myofibril after Treatment with Pepsin at pH 5.0.

Pepsin treatment: $1.5 \mathrm{mg} / \mathrm{ml}$ myofibril was incubated with or without pepsin $(14 \mathrm{mU} / \mathrm{ml}$ or $28 \mathrm{mU} / \mathrm{ml}$ ) in $0.15 \mathrm{M} \mathrm{KCl}-5 \mathrm{~mm} \mathrm{Na}$-acetate-HCl buffer solution at $\mathrm{pH} 5.0$ and $3^{\circ} \mathrm{C}$ for 3 days.

ATPase was assayed as in Fig. 1.

Symbols are the same as in Fig. 3.

$\sin$ D. The denaturation was performed by incubating myofibril in $0.15 \mathrm{M} \mathrm{KCl}$ at $37^{\circ} \mathrm{C}$ and $\mathrm{pH} 5.5$ for $2 \mathrm{hr}$. The $\mathrm{Mg}$-enhanced ATPase activity was depressed by $20 \%$ of the initial value by this treatment. When this partially-denatured myofibril was incubated at $3^{\circ} \mathrm{C}$ and $\mathrm{pH} 5.5$ with $28 \mathrm{mU} / \mathrm{ml}$ cathepsin $\mathrm{D}$, there was no change in ATPase activity, as shown in Fig. 6.

\section{DISCUSSION}

The present result indicated that cathepsin D hydrolyzed myofibril very slightly at postmortem condition and that nonprotein muscle extract and $\mathrm{Ca}^{2+}$ did not enhance the proteolytic action of cathepsin D on myofibril (Tables I and II). Busch et al. ${ }^{101}$ reported that the degradation of myofibril was accelerated by the addition of $\mathrm{Ca}^{2+}$ Presumed that this

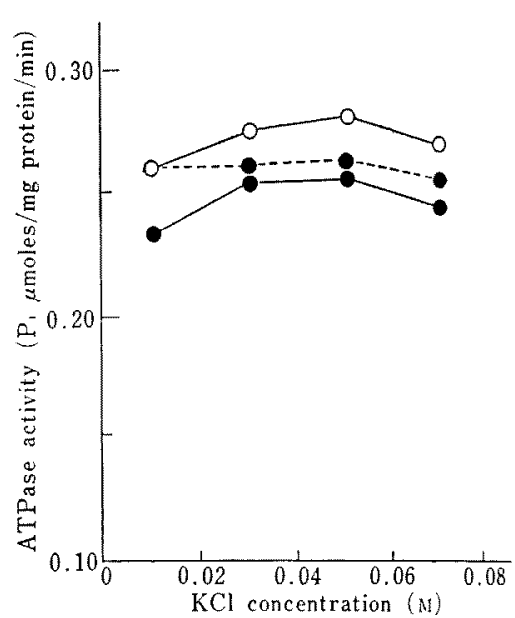

FIG. 6. ATPase Activity after Treatment of Partially-denatured Myofibril with Cathepsin D.

Cathepsin treatment: $1.5 \mathrm{mg} / \mathrm{ml}$ partially-denatured myofibril was incubated with or without cathepsin $\mathrm{D}(28 \mathrm{mU} / \mathrm{ml})$ in $0.15 \mathrm{M} \mathrm{KCl}-5 \mathrm{~mm} \mathrm{Na}$ acetate- $\mathrm{HCl}$ buffer solution at $\mathrm{pH} 5.5$ and $3^{\circ} \mathrm{C}$ for 10 days.

Partial denaturation was performed by incubating myofibril in $0.15 \mathrm{M} \mathrm{KCl}$ at $\mathrm{pH} 5.5$ and $37^{\circ} \mathrm{C}$ for $2 \mathrm{hr}$.

ATPase was assayed as in Fig. 1.

Symbols are the same as in Fig. 2.

phenomenon is ascribed to activities of some enzymes, cathepsin D may not be the member.

The $\mathrm{pH}$ dependence of the proteolytic action of cathepsin D on myofibril was similat to that on hemoglobin (Tables II and III). Because hemoglobin had been previously denatured with urea, it seemed that the denaturation rate during a catheptic treatment did not so vary with the $\mathrm{pH}$ of the incubation media. On the other hand, myofibril used as substrate was initially native and thereafter denatured at a different rate, being dependen on the $\mathrm{pH}$ of the incubation media. Wher myofibril was incubated at $3^{\circ} \mathrm{C}$ for 10 days the ATPase activity was most decreased a pH 4.0 and not decreased at pH 5.5 (Figs. and 4). The fact that the $\mathrm{pH}$ dependence 0 the proteolytic action of cathepsin $\mathrm{D}$ ot myofibril was similar to that on denature 
hemoglobin, although the extent of the denaturation of myofibril was so different as above mentioned, suggested that the proteolytic action of cathepsin D was not so influenced by the denaturation of myofibrilar proteins. This suggestion was not inconsistent with the result in Fig. 6.

Figure 2, 4 and 6 showed that cathepsin did not cause a change in the $\mathrm{Mg}$-enhanced ATPase activity of myofibril at post-mortem conditions. On the other hand, Figs. 3 and 5 indicated that pepsin at the concentration identical to cathepsin $\mathrm{D}$ caused an increase in the $\mathrm{KCl}$-concentration dependence of ATPase activity and a successive decrease in the maximal value of the ATPase activity. From our previous results, ${ }^{2}$ it seems that such a structural alteration as the post-mortem degradation may be inevitably accompany a change in the Mg-enhanced ATPase activity of myofibril. It has been also shown that the Mg-enhanced ATPase activity is always altered by the treatment of myofibril with a proteinase, trypsin ${ }^{9}$ or pepsin. Accordingly, from the present results, it is concluded that the proteolytic action of cathepsin D on myofibril is very weak while its action on hemoglobin is comparable with trypsin or pepsin and that cathepsin D may not be a main factor for the post-mortem degradation of myofibril.

Acknowledgement. This work was partly supported by a grant from Japan Association of Applied Enzyme. The authors with to express their thanks to Mr. Mutsumi Makinoda for his technical support.

\section{REFERENCES}

1) K. Takahashi, T. Fukazawa and T. Yasui, J. Food Sci., 32, 409 (1967); C. L. Davey and K. V. Gilbert, J. Food Teclmol,, 2, 57 (1967); idem, J. Food Sci, 34, 69 (1969); T. Fukazawa and T. Yasui, Biochim. Biophys. Acta, 140, 534 (1967); D. W. Henderson, D. E. Goll and M. H. Stromer, Am. J. Anat., 128, 117 (1970); M. H. Stromer, D. E. Goll and L. E. Roth, J. Cell Biol., 34, 431 (1967).

2) R. Yang, A. Okitani and M. Fujimaki, $A g r$. Biol. Chem., 34, 1765 (1970).

3) A. Suzuki and M. Fujimaki, ibid., 32, 975 (1968).

4) A. Suzuki, A. Okitani and M. Fujimaki, ibid, 33, 1723 (1969).

5) idem, ibid., 33, 579 (1969).

6) O. H. Lowry, N. J. Rosenbrough, A. L. Farr and R. J. Randall, J. Biol. Chem., 193, 265 (1951).

7) M. Nakamura, Nippon Nogeikagaku Kaishi, 24, $1(1950)$.

8) A. G. Gornall, C.S. Bardawaill and M. M. David, J. Biol. Chem., 177, 751 (1949).

9) K. Maruyama and S. Nagashima, J. Biochem., 62, 392 (1967).

10) W. A. Busch, M. H. Stomer, D. E. Goll and A. Suzuki, J. Cell Biol., 52, 367 (1972). 